Макогон Ю.В.

доктор економ. наук, професор, заслужений діяч науки і техніки

Донецький національний університет (м. Вінниия)

Пахомова О.A.

Донецький національний університет (м. Вінниия)

\title{
ЗОВНІШНІЙ БОРГ УКРАЇНИ НА СУЧАСНОМУ ЕТАПІ ЕКОНОМІЧНОЇ КРИЗИ
}

\section{ВНЕШНИЙ ДОЛГ УКРАИНЫ НА СОВРЕМЕННОМ ЭТАПЕ ЭКОНОМИЧЕСКОГО КРИЗИСА}

\section{EXTERNAL DEBT OF UKRAINE AT THE PRESENT STAGE OF THE ECONOMIC CRISIS}

Наукове дослідження присвячене оціниі та аналізу сучасного стану зовнішнього боргу України, виявленню динаміки та основних тенденцій розвитку зовнішньої заборгованості України на сучасному етапі економічної кризи та наданню подальшого розвитку науковопрактичних рекомендацій щуодо удосконалення політики зовнішнього боргу України в сучасних умовах функиіонування світового господарства. В науковій статті визначено теоретико-методологічні основи міжнародного кредитування, досліджено загальний вплив зовнішнього боргу на розвиток національних економік країн світу, розглянуто систему регулювання зовнішнього боргу Украӥни. В роботі надано оиінку динаміки та розвитку зовнішньої заборгованості Украӥни та проаналізовано сучасний стан розвитку зовнішнього боргу України. Розглянуто національний економічний потенціал України; розроблено механізм регулювання зовнішнього боргу Украӥни; запропоновано напрямки удосконалення вже існуючого механізму регулювання міжнародного кредитування в сучасних умовах економічної кризи.

Ключові слова: зовнішній борг, золотовалютні резерви, бюджетний дефіцит.

Научное исследование посвящено оценке и анализу современного состояния внешнего долга Украины, выявлению динамики и основных тенденций развития внешней задолженности Украины на современном этапе экономического кризиса и предоставлению дальнейтего развития научно-практических рекомендаций по совершенствованию политики внешнего долга Украины в современных условиях функиионирования мирового хозяйства. В научной статье определены теоретико-методологические основы международного кредитования, исследовано общее влияние внешнего долга на развитие начиональных экономик стран мира, рассмотрена система регулирования внешнего долга Украины. В роботе дана оченка динамики и развития внешней задолженности Украины и проанализировано современное состояние внешнего долга Украины. Рассмотрен наџиональный экономический потенциал Украины; разработан механизм регулирования внешнего долга Украины; предложены направления совершенствования уже существующего механизма регулирования международного кредитования в современных условиях экономического кризиса.

Ключевые слова: внешний долг, золотовалютные резервы, бюджетный дефицит. 
Research study on assessment and analysis of the current state of external debt of Ukraine, identification of the dynamics and the main development trends of external debt of Ukraine at the present stage of the economic crisis and provide further development of scientific-practical recommendations on improvement of policy of external debt of Ukraine in modern conditions of functioning of the world economy. In the scientific article the theoretical-methodological fundamentals of international lending, investigated the overall effect of external debt on the development of national economies of countries of the world, the system of external debt management of Ukraine. In work the estimation of the dynamics and development external debt of Ukraine and analyzes the current state of external debt of Ukraine. The national economic potential of Ukraine is considered; developed a mechanism of regulating external debt of Ukraine; the directions of improvement of the existing regulatory mechanism international crediting in modern conditions of the economic crisis.

Keywords: external debt, foreign reserves, budget deficit.

Вступ. Зовнішній борг виступає є досить суперечливою і актуальною тематикою. Звичайно в тій чи іншій мірі майже кожна країна світу зіткалася 3 необхідністю брати зовнішню позику, але нажаль не для кожної країни світу цей процес виявився позитивним. 3 іншого боку раціональне використання зовнішніх коштів підтримує економіку на необхідному рівні або сприяє активному економічному зростанню країни. Що ж до України, котра не є виключенням, то сучасний стан іiі зовнішнього боргу, на сьогодні виступає одним 3 найактуальніших питань, що зумовлено безпрецедентним обсягом зовнішнього боргу України та цілою низкою нищівних наслідків, що несе за собою безконтрольне використання зовнішніх займів.

Теоретико-методологічною основою наукового дослідження виступають роботи відомих вітчизняних вчених таких як Р.Р. Андрусів, В.Д. Базилевич, С.Я. Боринець, С.С. Галасанов, В.Д. Лагутін, С.Л. Лондар, С.В. Мочерний, Н.В. Стукало, О.В. Шлапак та інших. Щодо зарубіжної наукової школи, то це праці Л.В. Алмаші, А.Б. Вебер, Е. Герд, Д. Рікардо та інші.

Разом $з$ тим, у науковій літературі недостатньо уваги приділено саме аналізу сучасному стану зовнішнього боргу України. Оскільки на сьогодні процес $є$ динамічним, статистичні дані постійно оновлюються, тобто виникає необхідність періодичної оцінки та аналізу зовнішньої заборгованості України на певному проміжку часу, що зумовило актуальність обраної теми дослідження, їі цільове спрямування і зміст.

Постановка завдання. Метою дослідження виступає визначення основних показників розвитку зовнішнього боргу України та визначення напрямків регулювання процесу.

Комплексний підхід до реалізації поставленої мети окреслив коло завдань, які передбачалося вирішити при підготовці наукового дослідження:

- розкрити понятійно-категорійний апарат зовнішнього боргу;

- оцінити та проаналізувати обсяг зовнішнього боргу України;

- окреслити основні напрямки оптимізації зовнішнього боргу України. 
Об'єктом роботи виступають процеси зовнішніх запозичень в світовому господарстві. Предметом - сучасний стан зовнішнього боргу України.

Методологія. Методологічною базою дослідження є роботи відомих вітчизняних i зарубіжних вчених 3 питань зовнішньої заборгованості, нормативно-правові акти України та статистичні данні офіційних сайтів. Методологічний апарат дослідження складають: загально-наукові методи дослідження (діалектичний метод пізнання, наукова індукція та дедукція, системний, метод порівняння і синтезу) та спеціальні економічні методи (структурного, дисперсійного, факторного аналізу).

Результати дослідження. Важливою ланкою в розвитку фінансового ринку України є зовнішній борг. Економічні негаразди країни змушують шукати зовнішні джерела фінансування, тим самим втягуючи країну в зовнішню заборгованість.

Міжнародний кредит зумовлює економічні відносини, які виникають між кредиторами i позичальниками різних країн 3 приводу надання використання та погашення позики. Кредитні відносини складаються на принципах: повернення, терміновості, платності, гарантованості.

На законодавчому рівні, згідно ст.2 Бюджетного кодексу України, державний борг визначається як загальна сума боргових зобов'язань держави 3 повернення отриманих та непогашених кредитів (позик).

За структурою державний борг України включає внутрішній та зовнішній. У 1992p. прийнято Закон «Про державний внутрішній борг України», згідно якого державний внутрішній борг України - це строкові боргові зобов'язання уряду України у грошовій формі.

У свою чергу державний зовнішній борг - це боргові зобов'язання держави перед нерезидентами щодо повернення позичених коштів (основна сума боргу) та відсотків за ними.

Так державний борг виникає як наслідок фінансових займів держави, договорів та угод щодо надання кредитів, пролонгації та реструктуризації боргових зобов'язань попередніх років. До боргових зобов'язань держави належить також гарантований державний борг, котрий виникає як наслідок взятих на себе державних гарантій щодо зобов'язань третіх осіб, або взятих на себе державою зобов'язань третіх осіб.

На сучасному етапі розвитку зовнішній борг України сягнув безпрецедентного рівня. У момент проголошення незалежності Україна мала нульовий рівень державного зовнішнього боргу, оскільки всі попередні зобов'язання після розпаду СРСР лягли на плечі Російської Федерації. Нажаль власних коштів Україні, як молодій незалежній державі не вистачило, оскільки свій шлях вона розпочала в тяжких фінансових умовах. Золотовалютні резерви колишнього СРСР майже повністю теж залишилися у Російської Федерації. Так у спадщину Україна з отриманням незалежності мала енерговитратну 
структуру економіки, що потребувала перебудови. Енергозалежність та обсяг валютних резервів не забезпечував стабільності грошової одиниці. Також значні кошти було витрачено суб'єктами господарювання та населенням в 90x pр. як наслідок лібералізації цін та гіперінфляції. Держава потребувала додаткових зовнішніх фінансових потоків.

В 1992p. Україною було отримано першу зовнішню позику, було залучено іноземних кредитів в рамках кредитних ліній, відкритих під гарантії Кабінету Міністрів України. В 1993р. збільшується гарантований боргу за експортними (товарними) кредитними лініями та покриття простроченої заборгованості перед Російською Федерацією збільшили зовнішній борг України. 75\% цього боргу становила заборгованість перед Російською Федерацією.

Протягом 1994-1996pp. зовнішній борг України зріс майже в 2,5 разів. В цей період були перші для України позики від міжнародних організацій (МВФ, СБРР, Світовий банк). Тобто було диверсифіковано джерела залучення кредитних ресурсів.

3 1997p. Україна розпочала зовнішні комерційні позики. На комерційних засадах кошти мобілізувалися через уповноважених агентів та під гарантії іноземних інвестиційних компаній. Проте зменшилось залучення коштів міжнародних організацій для фінансування дефіциту державного бюджету. Причина - гальмування виконання Україною заходів щодо докорінного реформування економіки.

Важливим у формуванні зовнішнього боргу України стало підписання в 1997р. угоди між Україною та Росією щодо взаєморозрахунків, пов'язаних 3 розподілом Чорноморського флоту та перебуванням російського флоту на території України. Згідно угоди з січня 1998р. Україна не здійснює грошових платежів на користь Росії в рамках обслуговування та погашення державного боргу, що відповідно поліпшує показники навантаження на державний бюджет та відношення обсягу обслуговування боргу до експорту.

У період 1999-2000pp. зовнішній борг характеризується використанням довгострокових методів та механізмів управління 3 метою реструктуризації зовнішнього боргу.

Значна трансформація боргової ідеології 3 кредиторами України спостерігалася в 2001-2004pp. Характерним стає зменшення боргової залежності, також для фінансування поточних витрат бюджету забороняється використовувати зовнішні позики. Заміняються зовнішні джерела фінансування на внутрішні, зосередження на оптимальних джерелах фінансування.

У 2005-2007 pр. економічна ситуація України змінюється, що супроводжується зростанням бюджетного дефіциту, розпочинається впровадження заходів ефективного управління внутрішнім державним боргом, 
частка внутрішніх джерел фінансування зростає. Україна значно зменшує фінансове боргове навантаження зовнішніх джерел.

Нажаль подальший стан економіки України погіршується. Так 2008-2009pр. характеризується нестачею державних фінансових ресурсів, що зумовлено світовою фінансовою кризою. Пік фінансової кризи в Україні припав на 2010p. 3 2010p. зовнішній борг збільшується шаленими кроками та на 31.12.2015p. сукупний борг України становить 1 571,77 млрд. грн, 3 них 66\% (1 042,31 млрд. грн.) припадає на зовнішній борг країни (рис.1).

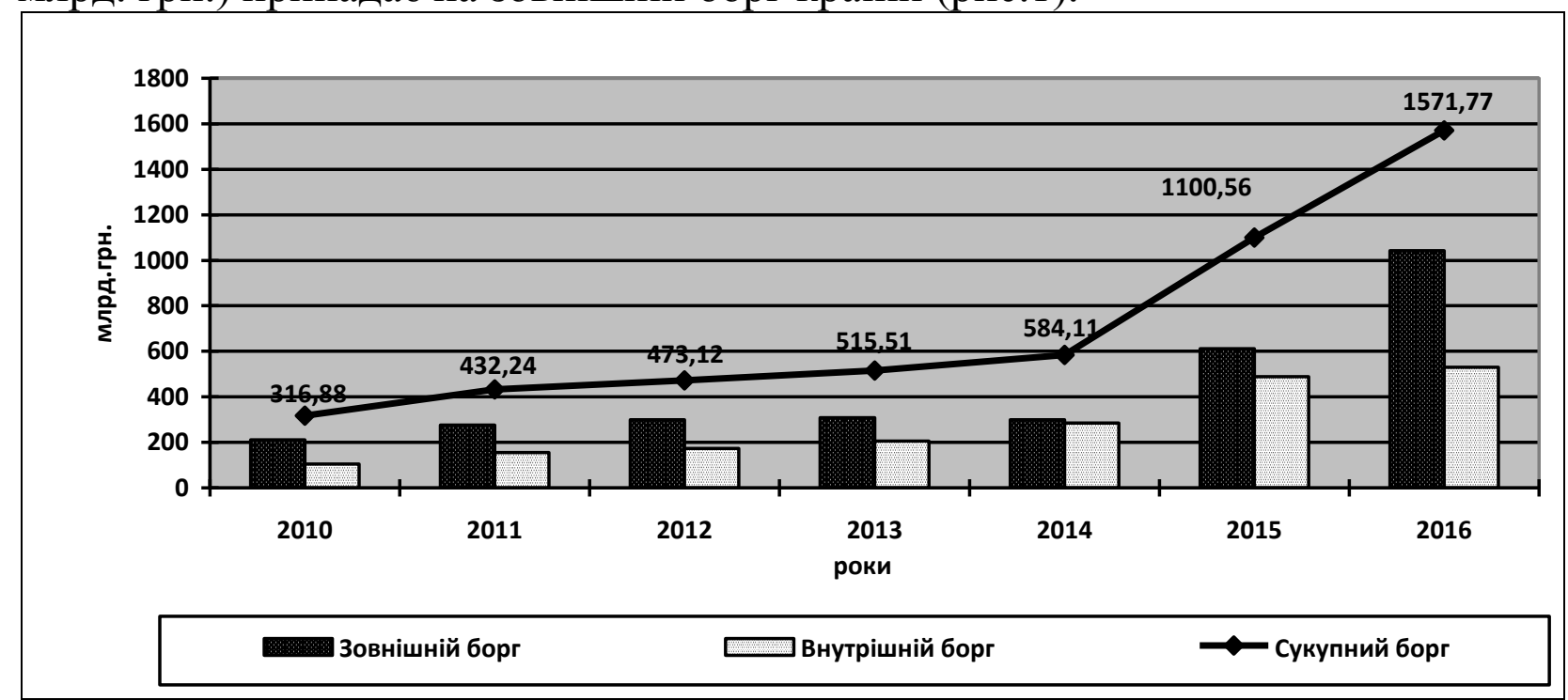

Рис. 1. Динаміка обсягу зовнішнього та внутрішнього боргу України, млрд. грн. 2010-2016pp. [8]

За структурою борг України на 31.12.2015p. здебільшого складався 3 державного зовнішнього боргу, що складає більше половини сукупного обсягу (53\%), тобто 825,86 млн. грн. (рис. 2).

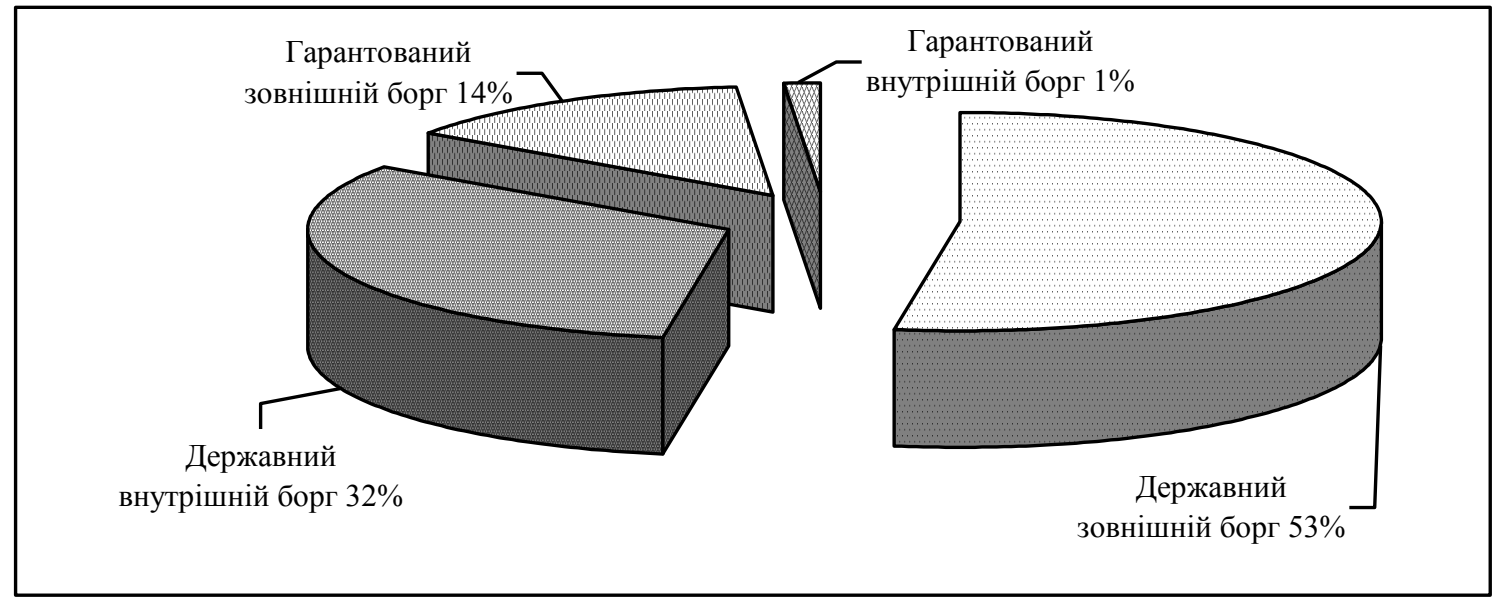

Рис. 2. Структура державного боргу України станом на 31.12.2015p. [8] 
До того ж впродовж січня-грудня 2015 року сума державного та гарантованого державою боргу України в доларах США зменшилася на 4,32 млрд. дол. США. Здебільшого через проведену реструктуризацію та списання частини державного та гарантованого державою зовнішнього боргу боргу.

В той же час, державний та гарантований борг у гривневому еквіваленті збільшився на 470,93 млрд. грн. через девальвацію національної валюти, курс якої зріс з близько 15,77 грн./дол. США на кінець 2014p. до близько 24,00 грн./дол. США на кінець грудня 2015p.

За валютною структурою державного та гарантованого боргу України на 31.12.2015p. найбільша частка припадає на долар США - 44\% загального обсягу (рис.3). Такий розподіл в свою чергу, ще більше погіршує борговий стан України та робить важчим процес погашення боргових зобов'язань, оскільки валюта долар США на сьогодні $є$ найбільш дорогою та найменш знецінилася за останні роки.

Підбиваючи підсумки статистичних даних зазначимо, що настільки безконтрольне споживання боргових зобов'язань, особливо у вигляді зовнішніх фінансових потоків дуже небезпечно. Оскільки виникає ризик гіперінфляції, який погіршує загальний економічний стан та інвестиційну привабливість країни, таким чином перешкоджаючи економічному зростанню України.

Звичайно державне управління зовнішнім боргом повинно мати свої раціональні межі, згідно яких зовнішні запозичення мають позитивний вплив на економіку країни. В противному випадку зовнішній борг може гальмувати розвиток фінансової системи. Як наслідок зниження рівня боргової безпеки держави, погіршення iï фінансової стійкості, блокування зарубіжними інвесторами та навіть банкрутство.

Згідно наукових досліджень безпечний рівень державного i гарантованого державою боргу для України становить близько $35 \%$ від ВВП. На сьогодні Україна має критичне значення. При цьому, нажаль джерелом надходження фінансів для виповнення боргових зобов'язань значною мірою $є$ нові кредити, котрі, без направлення в реальний сектор економіки, лише погіршують фінансовий стан держави. При чому переважними кредиторами України є США та МВФ, що в свою чергу посилює залежність економіки потужної та незалежної України від іноземних інвесторів, тим самим певною мірою втрачаючи власну свободу щодо самовизначення. 


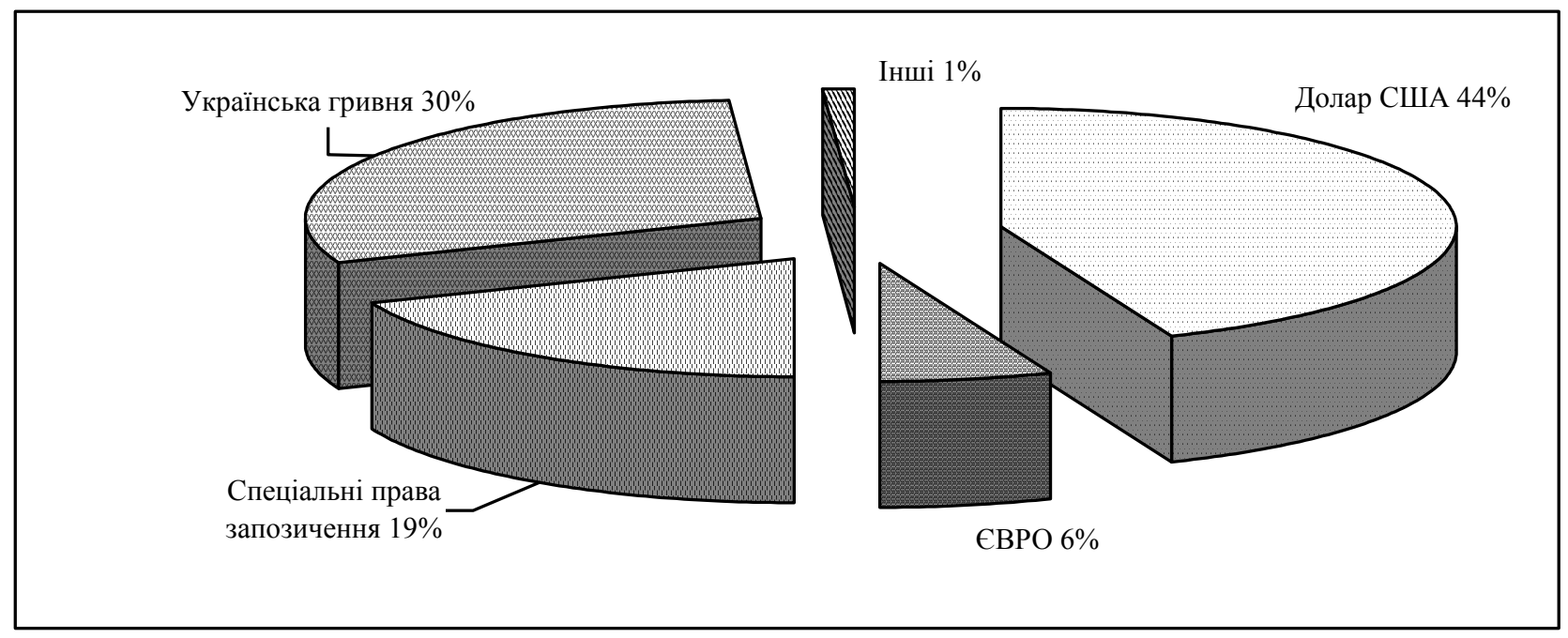

Рис. 3. Валютна структура сукупного державного та гарантованого державою боргу України станом на 31.12.2015p. [9]

Тож основними засадами управління державним боргом має бути: мінімізація витрат та ризиків пов'язаних 3 боргом; оптимізація структури боргу; розвиток внутрішнього ринку державних запозичень. Велике значення в оптимізації зовнішнього боргу України має прозорість використання наданих коштів.

Формуючи політику держави в галузі зовнішнього боргу доцільно використовувати наступні заходи:

- розробити механізм збалансування витрат та доходів у бюджетних системах, що є основою централізованих фінансів;

- впровадити кількісний та якісний аналіз залежності фінансової дестабілізації бюджетної системи від внутрішніх і зовнішніх чинників;

- виявити перелік чинників не контрольованих державою;

- підвищувати ефективність інвестування додаткових бюджетних доходів.

Важливо зазначити, що для зменшення боргового навантаження та зменшення ризику виникнення дефолту України, було проведено реструктуризацію боргу. Як наслідок проведених Урядом України в 2015p. переговорів 3 клубом кредиторів України було досягнуто згоду щодо реструктуризації боргу України. В угоді йшлося про списання 20\% боргу та продовження на чотири роки терміну погашення українських єврооблігацій. Але питання реструктуризації $\epsilon$ спірним, оскільки постійне відкладання повернення боргу перекладає боргове навантаження, що сягнуло безпрецедентних обсягів за короткий проміжок часу, на плечі майбутніх поколінь. Зумовлюючи вищенаведене, підкреслимо, що проект бюджету України на 2016p. вже повністю прив'язаний до погашення зовнішнього боргу. 
Висновки. Таким чином проведене дослідження дозволяє зробити певні висновки:

- На законодавчому рівні, згідно ст.2 Бюджетного кодексу України, державний борг визначається як загальна сума боргових зобов'язань держави 3 повернення отриманих та непогашених кредитів (позик). За структурою державний борг України включає внутрішній та зовнішній. У 1992р. прийнято Закон «Про державний внутрішній борг України», згідно якого державний внутрішній борг України - це строкові боргові зобов'язання уряду України у грошовій формі. У свою чергу державний зовнішній борг- це боргові зобов'язання держави перед нерезидентами щодо повернення позичених коштів (основна сума боргу) та відсотків за ними.

- 3 моменту отримання незалежності зовнішній борг України пройшов довгий шлях, країна для подальшого розвитку потребувала певних зовнішніх запозичень. На сьогодні зовнішній борг склав безпрецедентного розміру. Станом на 31.12.2015p. сукупний борг України становить 1 571,77 млрд. грн, 3 них 66\% (1 042,31 млрд. грн.) припадає на зовнішній борг країни. За валютною структурою державного та гарантованого боргу України на 31.12.2015p. найбільша частка припадає на долар США - 44\% загального обсягу. Такий розподіл в свою чергу, ще більше погіршує борговий стан України та робить важчим процес погашення боргових зобов'язань, оскільки валюта долар США на сьогодні є найбільш дорогою та найменш знецінилася за останні роки.

- Згідно наукових досліджень безпечний рівень державного i гарантованого державою боргу для України становить близько $35 \%$ від ВВП. На сьогодні Україна має критичне значення. При цьому, нажаль джерелом надходження фінансів для виповнення боргових зобов'язань значною мірою $\epsilon$ нові кредити, котрі, без направлення в реальний сектор економіки, лише погіршують фінансовий стан держави.

Тож основними засадами управління державним боргом має бути: мінімізація витрат та ризиків пов'язаних 3 боргом; оптимізація структури боргу; розвиток внутрішнього ринку державних запозичень. Велике значення в оптимізації зовнішнього боргу України має прозорість використання наданих коштів.

Формуючи політику держави в галузі зовнішнього боргу доцільно використовувати наступні заходи: розробити механізм збалансування витрат та доходів у бюджетних системах, що є основою централізованих фінансів; впровадити кількісний та якісний аналіз залежності фінансової дестабілізації бюджетної системи від внутрішніх і зовнішніх чинників; виявити перелік чинників не контрольованих державою; підвищувати ефективність інвестування додаткових бюджетних доходів. 
Наукова новизна проведеного аналізу полягає у формуванні методичного підходу щодо вдосконалення механізму державного регулювання зовнішнього боргу України, що грунтується не стільки на залученні досвіду передових країн світу, скільки на аналізі причиннонаслідкових зв'язків всередині країни. Практичне значення наукового дослідження сформоване визначенням стану зовнішнього боргу України в сучасних умовах економічної кризи. Подальші перспективи наукових розробок за даним напрямком полягають у визначенні більш детальної схеми регулювання зовнішнього боргу України та визначенню напрямків оптимізації вже існуючого механізму регулювання процесу в Україні.

\section{Література:}

1. Боринець С.Я. Моделі організаційного забезпечення управління державним боргом: світовий досвід та перспективи для України / С.Я. Боринець, Л.В. Могилко // Банківська справа. - 2012. - № 4. - С. 43-66.

2. Внешний долг Украины. Статистика, динамика, структура - Инсайдер [Электронный pecypc] // Insider.pro: [сайт] - 2015. - Режим доступа: http://insiders.com.ua/spravochnik/vneshnij-dolg

3. Герд Е. Управління державним боргом: завдання, цілі, учасники / Е. Герд // Фінанси України. - 2014. - № 1. - С. 7-21.

4. Гасанов С.С. Напрями формування фіскальної політики в аспекті асоціації України 3 ЄС / С.С. Гасанов, В.П. Кудряшов, Р.Л. Балакін // Фінанси України. - 2014. - № 1. - С. 22 38.

5. Офіційний сайт Верховної Ради України [Електронний ресурс]. - Режим доступу: http://zakon4.rada.gov.ua/laws

6. Офіційний сайт Державної служби статистики України [Електронний ресурс]. Режим доступу: http://www.ukrstat.gov.ua

7. Офіційний сайт Міжнародного валютного фонду [Електронний ресурс]. - Режим доступу: http://www.imf.org

8. Офіційний сайт Міністерства фінансів України [Електронний ресурс]. - Режим доступу: http://index.minfin.com.ua/index/debtgov/

9. Офіційний сайт Міністерства фінансів України [Електронний ресурс]. - Режим доступу: http://www.minfin.gov.ua/news/view/statystychni-materialy-shchodo-derzhavnoho-taharantovanoho-derzhavoiu-borhu-ukrainy-u--rotsi?category=borg\&subcategory=statistichnainformacija-schodo-borgu

10. Покрас О. С. Зависимость между устойчивым развитием и обьемом внешнего долга, и ее глобальный аспект / О. С. Покрас, С. В. Войтко // Науково-технічний розвиток: економіка, технологія, управління : матер. 12-ої Міжнар. наук.-практ. конф. - К.: НТУУ «КПІ», 2013. - С. 108.

11. Шлапак О.В. Державні фінанси України в сучасних умовах: проблеми стабілізації та антикризового управління / О.В. Шлапак // Фінанси України. - 2014. - № 4. - С. 7-31.

12. Янкова В. С., Войтко С. В. Системно-структурний аналіз в управлінні зовнішнім боргом України /В. С. Янкова, С. В. Войтко // Міжнародна економіка: інтеграція науки та практики : збірн. наук. праць. Вип. 3. - К.: ВПІ ВПК «Політехніка», 2013. - С. 214 - 221. 